\title{
POTENTIAL APPLICATION OF MICROALGAE IN ANIMAL PRODUCTION
}

Department of Production Systems and Environment, National Research Institute of Animal Production, Balice, Poland

\begin{abstract}
This article discusses the possibility of using microalgae in livestock production, with special reference to reducing harmful and noxious gas pollutant emission. Taking into consideration ongoing climate crisis the issue linked with reduction of gases from intensive animal production is a key important. Research shows that photosynthesizing properties of algae can be utilized for $\mathrm{CO}_{2}$ sequestration. Microalgae may be used as a method to reduces emissions of harmful gaseous components from natural fertilizers while enriching microalgae in $\mathrm{N}$ and $\mathrm{P}$ from manure or slurry. It is also worth noting that studies' results show microalgae biomass may be used as a substrate for biofuel production and as a feed additive partly replacing cereals in animal diets. The possiblity of applying microalgae as a feed additive was confirmed in studies, where microalgal powder (MAP) was used in layer feeding. MAP - supplementation causes improvements in egg quality. Microalgae may be used as an alternative to fish oil in cows' diets, causing increase in content of cis-9, trans-11 CLA in milk. Another important use of the unicellular algal biomass in agriculture is biogas production. The aim of this article is to review and systematize the current state of knowledge on topic of the application microalgae in animal production.
\end{abstract}

Key words: microalgae, animal production, gas pollutant emission.

\section{INTRODUCTION}

Ongoing climate change is one of the biggest environmental concerns of our time. This process is mainly driven by greenhouse gases (GHG), which contain carbon dioxide among others (Caro et al. 2014). Although it is naturally present in nature, the anthropogenic production of carbon dioxide exceeds the natural capacity for removal from the atmosphere, which leads to higher levels of pollution (Jentsch et al. 2009). In the 21st century, the emission of carbon dioxide into the atmosphere will cause the global temperature to increase by $1.1-2.9^{\circ} \mathrm{C}$ or, according to a more pessimistic estimate, by as much as $2.4-6.4^{\circ} \mathrm{C}$ (IPCC 2007). The agricultural sector contributes $18 \%$ of the world's anthropogenic GHG emissions, including $9 \%$ of $\mathrm{CO}_{2}$ emissions. Due to a positive birth rate, the world's population is projected to reach 9.3 billion by 2050. According to Cohen (2001), it is estimated that animal production may double by that time. In view of increasing greenhouse gas emissions, it is important to seek sustainable technological and environmental solutions to remedy this problem (Skuce et al. 2013). The emissions of harmful gaseous substances caused by livestock production depend on many factors such as species, herd size, stocking density, type of ingested feed.

Corresponding author: Wojciech Krawczyk, Department of Production Systems and Environment, National Research Institute of Animal Production, Krakowska 1, 32-083 Balice, Poland, e-mail: wojciech.krawczyk@izoo.krakow.pl, ORCID: 0000-0001-8235-5267. 
The agricultural sector faces the challenge of adapting to increased livestock production to meet the consumption needs while adapting to sustainable technologies that reduce the environmental impact of greenhouse gases. In the context of emissions from the livestock sector, an important role is played by legislation, including the Nitrates Directive (91/676/EEC) and the NEC Directive, which oblige EU countries to develop and implement methods reducing the deposition and emission of biogenic phosphorus and nitrogen compounds.

One of the solutions to these problems could be to use unicellular algae (microalgae) as biological material in broadly defined livestock production, e.g. as feed additives, for purification of natural fertilizers or carbon sequestration.

The aim of this paper is to review the latest literature on the use of microalgae in animal production.

\section{MICROALGAE}

Microalgae are photosynthetic autotrophic microorganisms defined as thallophytes. They belong to a highly divergent group that occurs in unicellular, filamentous or colonial forms. Microalgae most often live in freshwater and saltwater habitats or in wet lands. They are considered one of the oldest primitive forms of plant life (Brennan and Owende 2010). They vary from several to several hundred millimeters in size (Kamyab et al. 2015). Every single microalgal cell has the chloroplast, an essential organelle for conducting photosynthesis. More than 40.000 species of microalgae have been described (Kumar et al. 2010). Depending on strain, algae show various properties and tolerance to environmental conditions. Brennan and Owende (2010) report that $1 \mathrm{~kg}$ of dry microalgal biomass utilize about $1.83 \mathrm{~kg}$ of $\mathrm{CO}_{2}$. The species with the highest potential to capture $\mathrm{CO}_{2}$ are green and golden microalgae, and cyanobacteria (Kumar et al. 2010). Furthermore, their growth kinetics, $\mathrm{CO}_{2}$ capture rate and photosynthesis conditions vary according to strain.

\section{CULTURE PARAMETERS AFFECTING BIOMASS PRODUCTION EFFICIENCY}

Nutrients, $\mathrm{pH}$, temperature and light intensity are important factors affecting the efficiency of biomass production by microalgae. Microalgae require nutrients (substances containing nitrogen or phosphorus, and, in smaller amounts, magnesium, potassium, iron and cobalt) for optimal photosynthesis (Ota et al. 2009). In their study on the efficiency of biomass production, Vo et al. (2018) determined the N : P ratio in culture medium to ensure optimum development conditions and to regulate algal metabolism, while indicating the potential use of effluents (including agricultural or urban runoff containing large amounts of biogenic compounds) for fertilizing microalgal culture, in accordance with sustainable technology policy (Zhou et al. 2011). The findings of Perez-Garcia et al. (2011) showed that also the culture $\mathrm{pH}$ value is an important contributing factor to the growth kinetics of algae as a parameter affecting the activity of metabolic pathways and other processes occurring in microalgal cells (e.g. intracellular transport). The above experiments also provided evidence that proper $\mathrm{pH}$ value protects against pathogenic agents (Rodolfi et al. 2009). 
Ugwu et al. (2005) demonstrated that most species of algae develop well in temperatures between 15 and $30^{\circ} \mathrm{C}$. In addition, some species selected from such locations as hot springs and peat bogs, are more heat tolerant (Sakai et al. 1995). One such species is Chlorella sp. $K R-1$, which at $40^{\circ} \mathrm{C}$ is characterized by high growth kinetics and high culture density (Sung et al. 1999). The described organisms require proper light intensity and regulation of the lightdark cycle for normal biochemical reactions connected with this process (Vanags et al. 2015). The kinetic growth of microalgae is proportional to light intensity, up until reaching saturation threshold (Carvalho et al. 2011).

\section{SELECTION OF MICROALGAL STRAINS}

The most important step when modelling processes based on unicellular algae is to select a strain that has proper growth kinetics, is easy to culture, resistant to contamination, and produces biomass with appropriate composition which may serve as a substrate for producing high quality compounds (González López et al. 2009). Apart from the characteristics mentioned above, algae must show high mechanical resistance and be adapted to parameters such as $\mathrm{CO}_{2}$ concentration, temperature and $\mathrm{pH}$ of the environment (Zhou et al. 2011). Furthermore, the above species, which can exist in extreme conditions (e.g. hot springs) exhibit high resistance to temperature or high $\mathrm{SO}_{x}$ and $\mathrm{NO}_{x}$ concentrations. The strain selection process involves sampling from ecosystems, isolation and screening. Selection of novel microalgal strains is an important scientific challenge and the objective of several research projects, one of them being the Aquatic Species Program, which was concerned with microalgae research in the United States (Sheehan et al. 1998).

\section{THE POSSIBILITY OF USING MICROALGAE IN ANIMAL PRODUCTION}

There are many studies on the application of unicellular algae in animal production. They are concerned with the use of these organisms for reducing emissions of harmful substances from agriculture and as biomass for various purposes, e.g. as a substrate in biofuel production or as a feed additive.

Mulbry et al. (2005) described an alternative method of using inorganic fertilizers based on unicellular algal biomass. Their study was aimed to adapt the organisms for nutrient recovery from animal manure. As described above, these organisms require proper nutrients (among others, substances containing phosphorus and nitrogen) for normal development and for achieving high biomass production efficiency. To this end, the authors used technology in which nutrients were recovered from anaerobically digested manure. Biomass was produced from laboratory-scale algal turf scrubbers (ATS) using digested manure. The biomass was sieved through a $2 \mathrm{~mm}$ mesh screen, air-dried for $48 \mathrm{~h}$, ground using a Wiley Mill, and sieved again. Total nitrogen and total phosphorus were determined using ICP (induced coupled plasma) analysis. Comparison of ATS biomass with a commercial fertilizer showed that 20-day-old cucumber and corn seedlings contained comparable amounts of nutrients. Both sources increased plant growth, and no $\mathrm{NH}_{3}$ emission was observed for the fertilizer obtained from algal biomass. The described method allowed producing a fertilizer useful for plant cultivation while reducing nutrient loss from natural fertilizers. This reduced $\mathrm{NH}_{3}$ emissions as well as nitrogen and phosphorus runoff into waters. 
This research was followed up by experiments conducted in 2003-2006 (Mulbry et al. 2008), which were aimed to use unicellular algae for nutrient recovery from manure effluent using outdoor pilot-scale ATS raceways. The biomass was produced in four ATS raceways (30 $\mathrm{m}^{2}$ each) over the 4 years for 270 days each year. The raceways were colonized by algal consortia dominated by Rhizoclonium hieroglyphicum (C.A. Agardh), Microspora willeana Lagerh, Ulothrix ozonata (Weber and Mohr) Kütz, Rhizoclonium hieroglyphicum (C.A. Agardh) Kütz and Oedogonium sp. Algal biomass was harvested every 4-12 days and analysed for moisture, crude ash, total nitrogen and total phosphorus content. The effect of $\mathrm{CO}_{2}$ on algal growth and recovery of nutrients from manure was also investigated. The study showed no statistically significant differences between the results obtained for algal biomass supplemented with manure and that supplemented with manure and $\mathrm{CO}_{2}$. Algal productivity was not stable throughout the year and growth efficiency during the summer months was lower, probably due to hot weather. In terms of biomass productivity and recovery of nutrients from manure, the results of the industrial-scale experiment matched those obtained in the laboratory-scale experiment.

Studies of similar scope were also conducted in Europe. Godos et al. (2009) investigated bioremediation of swine manure in 2 raceway HRAPs (high rate algal ponds) constructed in flexible white PVC. Each HRAP pond had the same dimensions: a working volume of 464 litres with a surface of $1.52 \mathrm{~m}^{2}$. Pretreated manure, the total suspended solid content of which was reduced by $70 \%$, was diluted 10 - and 20 -fold and pumped into HRAPs. The dilution was performed in order to allow light penetration in the cultivation medium. The ponds were operated from January to October. Total nitrogen and total phosphorus concentrations were analysed once a week. From July to September, total nitrogen removal from the manure, mainly as a result of the nitrification process, was $88 \pm 6 \%$, with biomass productivity ranging from 21 to $28 \mathrm{~g} / \mathrm{m}^{-2} \mathrm{~d}^{-1}$. Due to the high buffer capacity of swine manure, algal phosphorus uptake was only $10 \%$. From a practical point of view, the above research could prove important for the livestock sector because these methods enable reducing emissions from natural fertilizers while providing the algae with nutrients.

Another area in which unicellular marine algae are used in animal production is biofuel production. During this process, these organisms are subjected to lipid extraction to obtain defatted microalgal biomass (Kovač et al. 2013). Lum et al. (2013) demonstrated that this byproduct can replace cereals in animal nutrition. According to their study, a 7.5\% supplement of this biomass to weaner diets did not have any effect on parameters such as animal weight gains or blood parameters (Lum et al. 2012). A similar study was performed with broiler chickens (Austic et al. 2013) which received a soybean meal diet with $7.5 \%$ of microalgal biomass and supplemental amino acids. This did not reduce body weights throughout the rearing period compared to conventionally fed birds. The obtained research results confirmed that defatted microalgal biomass, due to a high content of docosahexaenoic acid (DHA) and eicosapentaenoic acid (EPA) can be successfully used as a new generation feed additive.

The objective of the study by Park et al. (2015) was to determine the effect of dietary inclusion of microalgal powder (MAP) on egg production, egg quality, fatty acid content of egg yolk, and blood chemical parameters of laying hens. A total of 216 layers were randomly allocated to three groups according to diet. The first group (control) received a conventional 
diet, while the second and third groups were fed $0.5 \%$ and $1 \%$ MAP, respectively. At the end of the experiment, no statistically significant differences were observed between the number of eggs produced and blood lipid content for the MAP-supplemented and control groups. There were improvements in egg quality (including yolk colour index and shell thickness) as well as a reduced n-6 to n-3 fatty acids ratio in the eggs. Kupczyński et al. (2011) in the review article present many results of the effect of microalgae as a feed additive on the content of fatty acids in cow's milk. Due to the high content of fatty acids (PUFA), including docosahexaenoic acid (DHA), microalgae may cause an increase in cis-9 and trans-11 CLA content in milk (Boeckaert et al. 2008). Schizochytrium sp. as a feed additive for cows caused a decrease in the content of short-chain fatty acids. In other studies, the same species used as a feed additive caused an increase in trans-11 $\mathrm{C} 18$ concentration and a decrease in the populations of microorganisms in the rumen (Boeckaert et al. 2007). Conclusion from the review article is that microalgae as a feed additive can be an alternative to fish oil in the cow's diet. At appropriate doses, this may lead to an increase in CLA, along with EPA and DHA. Demirbaş (2008) described a method for biofuel production from two strains of microalgae: Cladophora fracta and Chlorella protothecoides, and showed that the properties of microalgal and vegetable oil biodiesels do not differ. What is more, it is conjectured that the temperature ranges, in which they can be correctly used in compression-ignition engines, may be wider. Apart from biodiesel fuel, microalgal biomass can be also turned into green jet fuel or ethanol. In addition, biomass can be subjected to anaerobic fermentation to obtain biogas (Wądrzyk et al. 2012).

\section{CONCLUSIONS}

The research results reported above confirm that microalgae can be successfully used in livestock production. Their application will not only lower the emission of harmful gaseous components (including $\mathrm{GHG}$ ) into the atmosphere, but will also allow replacing the raw materials used as feed additives or for biofuel production. However, it should be highlighted that because from an economic perspective biopurification applied in microalgal technology is expensive, it is advisable to use combined techniques, such as those employed for lipid extraction from algae during biofuel production and to use the produced dry microalgal biomass as a feed additive.

\section{REFERENCES}

91/676/EEC. Council Directive of 12 December 1991 concerning the protection of watersagainst pollution caused by nitrates from agricultural sources.

Austic R.E., Mustafa A., Jung B., Gatrell S., Lei X.G. 2013. Potential and limitation of a new defatted diatom microalgal biomass in replacing soybean meal and corn in diets for broiler chickens. J. Agric. Food Chem. 61, 7341-7348.

Brennan L., Owende P. 2010. Biofuels from microalgae - a review of technologies for production, processing, and extractions of biofuels and co-products. Renew. Sustain. Energ. Rev. 14, 557-577.

Boeckaert C., Fievez V., Van Hecke D., Verstraete W., Boon N. 2007. Changes in rumen biohydrogenation intermediates and ciliate protozoa diversity afteralgae supplementation to dairy cattle. Eur. J. Lipid Sci. Technol. 109, 767-777. 
Boeckaert C., Vlaeminck B., Dijkstra J., Issa-Zacharia A., van Nespen T.,van Straalen W., Fievez V. 2008. Effect of dietary starch or micro alga supple-mentation on rumen rermentation and milk fatty acid composition of dairycows. J. Dairy Sci. 91, 4714-4727.

Caro D., Davis S.J., Bastianoni S., Caldeira K. 2014. Global and regional trends in greenhouse gas emissions from livestock. Clim. Change 126(1-2), 203-216.

Carvalho A.P., Silva S.O., Baptista J.M., Malcata F.X. 2011. Light requirements in microalgal photobioreactors: an overview of biophotonic aspects. Appl. Microbiol. Biotechnol. 89, 1275-1288.

Cohen J.E. 2001. World population in 2015: assessing the projections. Series Proceedings, Federal Reserve Bank of Boston, 46, https://www.fedinprint.org/items/fedbcp/y2001n46x11.html, access: 25.02.2019.

Demirbaş A. 2008. Production of biodiesel from algae oils. Energ. Source 31, 163-168.

Godos I., Blanco S., García-Encina P.A., Becares E., Muñoz R. 2009. Long-term operation of high rate algal ponds for the bioremediation of piggery wastewaters at high loading rates. Bioresour. Technol. 100(19), 4332-4339.

González López C.V., Acién Fernández F.G., Fernández Sevilla J.M., Sánchez Fernández J.F., Cerón García M.C., Molina Grima E. 2009. Utilization of the cyanobacteria Anabaena sp. ATCC 33047 in CO2 removal processes. Bioresour. Technol. 100, 5904-5910.

IPCC. 2007. Climate Change 2007: Impacts, adaptation and vulnerability. Contribution of Working Group II to the Fourth Assessment Report of the Intergovernmental Panel on Climate Change. Eds. M.L. Parry, O.F. Canziani, J.P. Palutikof, P.J. van der Linden, C.E. Hanson. Cambridge University Press, Cambridge, UK, 976.

Jentsch W.A., Piatkowski B., Derno M. 2009. Relationship between carbon dioxide production and performance in cattle and pigs. Archive Tierzucht. 52(6), 587-592.

Kamyab H., Mohd Fadhil M.D, Keyvanfar A., Abd Majid M.Z., Talaiekhozani A., Shafaghat A., Lee C.T., Shiun L.J., Ismail H.H. 2015. Efficiency of microalgae Chlamydomonas on the removal of pollutants from palm oil mill effluent (POME). Energy Procedia 75, 2400-2408.

Kovač Blagojević D., Simeunović J., Babić O., Mišan A., Milovanović I. 2013. Algae in food and feed. Food Feed Res. 40, 21-32.

Kumar A., Ergas S., Yuan X., Sahu A., Zhang Q., Dewulf J., Malcata F.X., Langenhove H. van. 2010. Enhanced $\mathrm{CO} 2$ fixation and biofuel production via microalgae: recent developments and future directions. Trends Biotechnol. 28, 371-80.

Kupczyński R., Janeczek W., Kinal S., Kuczaj M. 2011. Wykorzystanie alg morskich w modyfikacji profilu kwasów tłuszczowych mleka krów [Possibility of modifying the fatty acid profile of cow's milk]. Med. Weter. 67(5), 304-308 [in Polish]

Lum K., Roneker K.R., Lei X.G. 2012. Effects of various replacements of corn and soy by defatted microalgal meal on growth performance and biochemical status of weanling pigs. J. Anim. Sci. 4 (Suppl. 3), 701.

Lum K.K., Kim J., Lei X.G. 2013. Dual potential of microalgae as a sustainable biofuel feedstock and animal feed. J. Anim. Sci. Biotechnol. 4(1), 53.

Mulbry W., Kondrad S., Pizarro C., Kebede-Westhead E. 2008. Treatment of dairy manure effluent using freshwater algae: Algal productivity and recovery of manure nutrients using pilot-scale algal turf scrubbers. Bioresour. Technol. 99(17), 8137-8142.

Mulbry W., Westhead E.K., Pizarro C., Sikora L. 2005. Recycling of manure nutrients: use of algal biomass from dairy manure treatment as a slow release fertilizer. Bioresour. Technol. 96(4), 451-458.

Ota M., Kato Y., Watanabe H., Watanabe M., Sato Y., Smith R.L., Inomata H. 2009. Fatty acid production from a highly $\mathrm{CO}_{2}$ tolerant alga, Chlorocuccum littorale, in the presence of inorganic carbon and nitrate. Bioresour. Technol. 100, 5237-42.

Park J.H., Upadhaya S.D., Kim I.H. 2015. Effect of dietary marine microalgae (Schizochytrium) powder on egg production, blood lipid profiles, egg quality, and fatty acid composition of egg yolk in layers. Asian-Australas. J. Anim. Sci. 28(3), 391-397. 
Perez-Garcia O., Escalante F.M., de-Bashan L.E., Bashan Y. 2011. Heterotrophic cultures of microalgae: metabolism and potential products. Water Res. 45, 11-36.

Rodolfi L., Chini Zittelli G., Bassi N., Padovani G., Biondi N., Bonini G., Tredici M.R. 2009. Microalgae for oil: strain selection, induction of lipid synthesis and outdoor mass cultivation in a lowcost photobioreactor. Biotechnol. Bioeng. 102(1), 100-112.

Sakai N., Sakamoto Y., Kishimoto N., Chihara M., Karube I. 1995. Chlorella strains from hot springs tolerant to high temperature and high $\mathrm{CO}_{2}$. Energy Conv. Manag. 36, 693-696.

Sheehan J., Dunahay T., Benemann J., Roessler P. 1998. A look back at the US Department of Energy's aquatic species program: biodiesel from algae. National Renewable Energy Laboratory (Close-Out Report), National Renewable Energy Laboratory Cole Boulevard Golden, Colorado, No. 328.

Skuce P.J., Morgan E.R., Dijk J. van, Mitchell M. 2013. Animal health aspects of adaptation to climate change: beating the heat and parasites in a warming Europe. Animal 7, 333-345.

Sung K.D., Lee J.S., Shin C.S., Park S.C., Choi M.J. 1999. CO $\mathrm{CO}_{2}$ fixation by Chlorella sp. KR-1 and its cultural characteristics. Bioresour. Technol. 68, 269-273.

Ugwu C.U., Ogbonna J.C., Tanaka H. 2005. Light/dark cyclic movement of algal culture (Synechocystis aquatilis) in outdoor inclined tubular photobioreactor equipped with static mixers for efficient production of biomass. Biotechnol. Lett. 27(2), 75-78.

Vanags J., Kunga L., Dubencovs K., Galvanauskas V., Balode M., Grigs O. 2015. The effect of shaking, $\mathrm{CO}_{2}$ concentration and light intensity on biomass growth of green microalgae Desmodesmus communis. Environ. Res. Eng. Manag. 70, 73-79.

Vo H.N., Bui X.T., Nguyen T.T., Nguyen D.D., Dao T.S., Cao N.D., Vo T.K. 2018. Effects of nutrient ratios and carbon dioxide bio-sequestration on biomass growth of Chlorella $s p$. in bubble column photobioreactor. J. Environ. Manag. 8, 219, 1-8.

Wądrzyk M., Wolszczak J., Jakóbiec J. 2012. Nowe kierunki rozwoju źródeł biopaliw [Development trends of new biofuels sources]. Autobusy. Tech. Eksploat. Syst. Transport. 4, 188-196. [in Polish]

Zhou W., Li Y., Min M., Hu B., Chen P., Ruan R. 2011. Local bioprospecting for high-lipid producing microalgal strains to be grown on concentrated municipal wastewater for biofuel production. Bioresour. Technol. 102, 6909-6919.

\title{
ZASTOSOWANIE ALG JEDNOKOMÓRKOWYCH W PRODUKCJI ZWIERZĘCEJ
}

\begin{abstract}
Streszczenie. Omówiono możliwość wykorzystania mikroalg w produkcji zwierzęcej, ze szczególnym uwzględnieniem redukcji emisji szkodliwych domieszek gazowych, co ma ogromne znaczenie w rolnictwie, szczególnie intensywnym, w dobie trwającego kryzysu klimatycznego. Mikroalgi mogą być stosowane w metodach zmniejszających emisję szkodliwych domieszek gazowych z nawozów naturalnych, jednocześnie wzbogacając je w N i P z obornika lub gnojowicy. Warto również zauważyć, że biomasa mikroalg może być stosowana jako substrat do produkcji biopaliw i jako dodatek paszowy zastępujący zboża w żywieniu zwierząt. Możliwość zastosowania mikroalg jako dodatku paszowego została potwierdzona w badaniach, w których mączka mikroalgalna (MAP) była wykorzystywana jako dodatek paszowy dla niosek. Suplementacja MAP powodowała także poprawę jakości jaj. Mikroalgi posiadają potencjał aplikacyjny alternatywny dla oleju rybiego w żywieniu krów, powodując wzrost zawartości CIS-9, trans-11 CLA w mleku. Innym ważnym zastosowaniem jednokomórkowej biomasy glonów w rolnictwie jest produkcja biogazu. Celem tego artykułu jest przegląd i usystematyzowanie aktualnego stanu wiedzy na temat zastosowania mikroalg w produkcji zwierzęcej.
\end{abstract}

Słowa kluczowe: mikroalgi, produkcja zwierzęca, szkodliwe domieszki gazowe. 
